Gut, 1973, 14, 13-19

\title{
The response to prednisolone in atrophic gastritis: a possible effect on non-intrinsic factor-mediated vitamin $\mathrm{B}_{12}$ absorption
}

\author{
R. G. STRICKLAND, JUNE M. FISHER, K. LEWIN, AND K. B. TAYLOR ${ }^{1}$ \\ From the Departments of Medicine and Pathology, Stanford University School of Medicine, \\ Stanford, California, USA
}

SUMMARY The administration of prednisolone did not affect absorption of vitamin $B_{12}$ and gastric secretion of intrinsic factor in nine subjects with normal gastric mucosa, or in five with chronic superficial gastritis. No gastric morphological changes were observed in either group. In contrast, four of seven patients with pernicious anaemia showed improvement in absorption of vitamin $\mathbf{B}_{12}$ during prednisolone administration for periods of two to 10 months. No consistent changes in gastric mucosal morphology were noted. An additional five patients were studied intensively during one month of prednisolone administration. In three, absorption of vitamin $\mathbf{B}_{12}$ was restored to within the normal range between eight and 13 days after the commencement of the drug. The improvement was not paralleled by enhancement of secretion of intrinsic factor or other vitamin $\mathbf{B}_{12}$ binders. Suppression of intrinsic factor antibodies in serum and gastric juice did not occur consistently in those patients showing a functional response.

Recent studies have shown that the enhancement of absorption of vitamin $B_{12}$ occurring with administration of corticosteroids to some patients with pernicious anaemia may correlate with enhanced output of gastric intrinsic factor (Ardeman and Chanarin, 1965; Jeffries, Todd, and Sleisenger, 1966; Rødbro, Dige-Petersen, Schwartz, and Dalgaard, 1967; Wall, Whittingham, Mackay, and Ungar, 1968; Baggett and Welsh, 1970). The specificity of this effect in pernicious anaemia has not, however, been established. We have therefore examined the effect of corticosteroids on the absorption of vitamin $B_{12}$ and secretion of intrinsic factor in subjects with normal gastric mucosa and chronic superficial gastritis as well as in those with advanced atrophic gastritis and pernicious anaemia.

It has been suggested (Fisher, Mackay, Taylor, and Ungar, 1967) that intrinsic factor antibodies present in the gastrointestinal tract may contribute to the vitamin $\mathbf{B}_{\mathbf{1 2}}$ malabsorption of pernicious anaemia. We have examined the possibility that the response to corticosteroids in patients with pernicious anaemia

${ }^{1}$ Requests for reprints should be addressed to Dr K. B. Taylor, Division of Gastroenterology, Stanford University School of Medicine, Stanford, California 94305.

Received for publication 7 November 1972. may be due to suppression of such intrinsic factor antibodies in serum or gastric juice or both.

An inconsistent but at times striking reappearance of parietal cells in the gastric mucosa has been described during corticosteroid administration (Ardeman and Chanarin, 1965; Jeffries et al, 1966; Rødbro et al, 1967; Wall et al, 1968). In the present study gastric biopsies were taken before, during, and after steroid administration in order to determine whether improvements in function are accompanied by improvement in mucosal structure.

\section{Patients and Methods}

The patients studied were divided into three groups.

\section{GROUP 1}

Nine male subjects without gastrointestinal or other disease, in whom gastric mucosal structure was normal.

\section{GROUP 2}

Five otherwise healthy male subjects in whom peroral biopsy of the stomach revealed the changes of chronic superficial gastritis without atrophy. Circulating gastric autoantibodies were not present in these subjects. 
GROUP 3

Twelve patients (six females) with Addisonian pernicious anaemia.

Groups 1 and 2 were given prednisolone 20 $\mathrm{mg} /$ day orally for one month. Seven patients in group 3 received an average dose of $20 \mathrm{mg}$ prednisolone orally per day for periods of two to 10 months. The other five (four females) received $20 \mathrm{mg}$ prednisolone orally per day for one month.

Vitamin $\mathbf{B}_{\mathbf{1 2}}$ absorption was estimated by the Schilling test. An oral dose of ${ }^{57} \mathrm{Co}$ vitamin $\mathbf{B}_{12}$, $0.5 \mu \mathrm{g}$, was used and the 24-hour urinary excretion of radioactivity measured (lower limit of the normal range is $10 \%$ of the administered dose). Gastric juice was collected by intermittent hand suction for 60 minutes in the basal state and for 75 minutes following intramuscular injection of histalog in a dose of $1.7 \mathrm{mg} / \mathrm{kg}$ body weight. Gastric acidity was determined by electrometric titration with $0 \cdot 1 \mathrm{~N} \mathrm{NaOH}$ to $p \mathrm{H} \mathrm{7 \cdot 4}$. In all subjects intrinsic factor and intrinsic factor antibody determinations were made in gastric juice collected for 75 minutes following the injection of histalog $(1.7 \mathrm{mg} / \mathrm{kg}$ body weight) using the technique of continuous intragastric instillation of $0.07 \mathrm{M}$ phosphate buffer as previously described (Strickland, Ashworth, Koo, and Taylor, 1969).

Intrinsic factor $\mathbf{B}_{\mathbf{1 2}}$-binding and non-specific $\mathbf{B}_{12}$-binding were measured by immunoassay (Gottlieb, Lau, Wasserman, and Herbert, 1965), the results being expressed in $\mathrm{ng}$ per $\mathrm{mg}$ total gastric juice protein. The latter was measured by the method of Lowry, Rosebrough, Farr, and Randall (1951).

Circulating parietal cell antibody was detected by immunofluorescence and complement fixation (Donnelly, 1951). IF antibodies of the 'blocking' and 'binding' types (types I and II) were detected in serum and gastric juice by the guinea pig mucosal homogenate assay (Ashworth, England, Fisher, and Taylor, 1967; Strickland, Baur, Ashworth, and Taylor, 1971).
Gastric biopsy specimens were obtained using a multipurpose peroral biopsy tube (Brandborg, Rubin, and Quinton, 1969). The tube was positioned in the mid-body of the stomach under fluoroscopic control. Serial sections $(6 \mu)$ were stained with haematoxylin and eosin and phosphotungstic acidhaematoxylin to display parietal cells. Sections were coded and examined by light microscopy independently by three different observers. The degrees of atrophy and inflammatory cell content were scored on a 0 to +++ scale. In order to obtain a numerical estimate of parietal cells in any given biopsy a parietal cell count was performed and expressed as the ratio of the number of gastric glands containing parietal cells to the total number of gastric glands per histological section. The number of parietal cells per gland were then estimated on a + to ++++ scale. Some sections showed severe gastric atrophy in which the glands were lined by cells with eosinophilic cytoplasm resembling parietal cells but lacking clear-cut granules and centrally situated nuclei. Such glands were scored as negative.

All subjects in groups 1 and 2 and the seven patients in group 3 who received prednisolone for periods up to 10 months had these parameters assessed at monthly intervals.

The remaining five patients in group 3 had frequent assessment of gastric function, vitamin $\mathbf{B}_{12}$ absorption, and gastric autoantibodies over the month when prednisolone was administered.

\section{Results}

GROUPS 1 AND 2 (NORMAL MUCOSA AND SUPERFICIAL GASTRITIS)

The effect of one month of oral prednisolone, $20 \mathrm{mg}$ per day, on vitamin $B_{12}$ absorption and the gastric secretion of vitamin $B_{12}$-binders in normal subjects and those with chronic superficial gastritis without atrophy is shown in Table I.

The minimal mean decrease in vitamin $\mathbf{B}_{12}$

\begin{tabular}{|c|c|c|c|c|c|c|}
\hline \multirow[t]{2}{*}{ Parameter } & \multicolumn{3}{|c|}{$\begin{array}{l}\text { Group I: Normal Subjects (9)1 } \\
\text { (prednisolone } 20 \text { mg per day) }\end{array}$} & \multicolumn{3}{|c|}{$\begin{array}{l}\text { Group II: Chronic Superficial Gastritis }(5)^{1} \\
\text { (Prednisolone } 20 \text { mg per day) }\end{array}$} \\
\hline & Before Steroid & 2 Weeks & 4 Weeks & Before Steroid & 2 Weeks & 4 Weeks \\
\hline $\begin{array}{l}\text { Schilling test (\% excretion per } \\
24 \mathrm{hr} \text { ) }\end{array}$ & $18 \cdot 1(5 \cdot 0)^{2}$ & $18 \cdot 2(4 \cdot 7)$ & $15 \cdot 3(5 \cdot 8)$ & $12 \cdot 8(1 \cdot 3)$ & $11.9(2 \cdot 6)$ & $9 \cdot 3(1 \cdot 4)$ \\
\hline $\begin{array}{l}\text { Intrinsic factor secretion } \\
\text { (ng per mg total protein) }\end{array}$ & $60 \cdot 6(20 \cdot 6)$ & N.T. & $57 \cdot 6(23 \cdot 8)$ & $77 \cdot 5(47 \cdot 8)$ & N.T. & $82.9(28.3)$ \\
\hline $\begin{array}{l}\text { Non-intrinsic factor secretion } \\
\text { (ng per mg total protein) }\end{array}$ & $13 \cdot 7(6 \cdot 6)$ & N.T. & $19 \cdot 3(13 \cdot 6)$ & $14 \cdot 8(8 \cdot 3)$ & N.T. & $16 \cdot 3(4 \cdot 6)$ \\
\hline
\end{tabular}

Table I Schilling tests and intrinsic factor and non-intrinsic factor $B_{12}$ binder secretion in subjects with normal gastric mucosal histology and chronic superficial gastritis receiving prednisolone.

${ }^{1}$ Figures in parentheses are number of subjects.

${ }^{2}$ Values are mean $\pm \mathrm{SD}$. Observed changes are not significant.

N.T. Not tested. 
absorption observed in both groups was not statistically significant. Gastric juice intrinsic factor and non-intrinsic factor $\mathbf{B}_{12}$-binding expressed in $\mathrm{ng}$ per $\mathrm{mg}$ protein were not significantly different in the two groups and no significant change in either occurred after one month of corticosteroid administration. The mean ratio of intrinsic to non-intrinsic factor $B_{12}$-binding was similarly not significantly altered by corticosteroids.

The appearances of the gastric mucosa were no different at the beginning and end of the course (Strickland, Fisher, and Taylor, 1969).

GROUP 3 (PERNICIOUS ANAEMIA): LONG-TERM STEROID ADMINISTRATION

Absorption of vitamin $B_{12}$ (Table II)

In four of the seven patients taking prednisolone for two to 10 months absorption of vitamin $B_{12}$ was temporarily restored to within, or close to, the normal range (lower limit of normal in our laboratory $10 \%$ ). This improvement disappeared following withdrawal of prednisolone, although in one subject absorption remained in the normal range for two months following discontinuation of the drug.
Secretion of vitamin $B_{12}$ binders

A serial study of gastric vitamin $B_{12}$ binders was made in five patients, two of whom had shown increase of vitamin $\mathbf{B}_{12}$ absorption to within the normal range, three of whom had not. In the former, the concentration of intrinsic factor $B_{12}$-binder rose from 0.6 to 6.4 (patient JP, Table II) and 5.0 to $9.5 \mathrm{ng}$ per $\mathrm{mg}$ (patient AD, Table II) whereas no activity was demonstrated before or after steroid administration in the other three.

An increase in total $B_{12}$ binding of gastric juice, attributable largely to an increase in non-intrinsic factor $B_{12}$-binders, occurred in four of the five patients during prednisolone administration. In only one of the four did the Schilling test show a significant increase (patient JP, Table II).

\section{Acid secretion}

In only one patient out of seven was any recovery of acid secretion noted (patient TR, Table II). After five months of prednisolone the gastric juice which had been consistently neutral showed a $p \mathrm{H}$ fall from 7.0 to 5.0 after histalog and the maximal acid output in one hour was 1.4 m-equiv. The maximal Schilling test

\begin{tabular}{|c|c|c|c|c|c|c|c|c|c|c|c|c|}
\hline \multirow[t]{2}{*}{ Patient } & \multicolumn{10}{|c|}{ Monthly Serial Biopsies } & \multicolumn{2}{|c|}{ Schilling Test } \\
\hline & $\begin{array}{l}\text { Before } \\
\text { Steroid }\end{array}$ & 1 & 2 & 3 & 4 & 5 & 6 & 7 & 8 & 9 & $\begin{array}{l}\text { Before } \\
\text { Steroid }\end{array}$ & $\begin{array}{l}\text { Maxi- } \\
\text { mum }\end{array}$ \\
\hline $\begin{array}{r}\text { T.R. } \begin{array}{l}1 \\
2 \\
3\end{array}\end{array}$ & $\begin{array}{l}(2) \\
44 \\
0 / 15 \\
0\end{array}$ & $\begin{array}{l}\text { (5) } \\
\text { Antral }\end{array}$ & $\begin{array}{l}\text { (6) } \\
\text { Antral }\end{array}$ & $\begin{array}{l}\text { (3) } \\
\text { Antral }\end{array}$ & $\begin{array}{l}(2) \\
54 \\
0 \cdot 15 \\
0\end{array}$ & $\begin{array}{l}(3) \\
54 \\
0 / 7 \\
0\end{array}$ & (1) & & & & 0 & 7 \\
\hline $\begin{array}{r}\text { A.D. } 1 \\
2 \\
3\end{array}$ & $\begin{array}{l}(1) \\
28 \\
19 / 25 \\
++ \\
(3)\end{array}$ & (2) & $\begin{array}{l}(2) \\
18 \\
8 / 13 \\
++ \\
(1)\end{array}$ & (3) & $\begin{array}{l}\text { (2) } \\
30 \\
11 / 19 \\
++\end{array}$ & (4) & $\begin{array}{l}(4) \\
52 \\
9 / 15 \\
++\end{array}$ & & & $\begin{array}{l}(3) \\
45 \\
7 / 18 \\
++\end{array}$ & 1 & 20 \\
\hline $\begin{array}{r}\text { E.C. } 1 \\
2 \\
3\end{array}$ & Antral & $\begin{array}{l}50 \\
0 / 15 \\
0\end{array}$ & $\begin{array}{l}32 \\
10 / 14 \\
++\end{array}$ & Antral & & $\begin{array}{l}(4) \\
9 \\
0 / 18 \\
0\end{array}$ & & & & & 0 & 2 \\
\hline $\begin{array}{r}\text { L.M. } 1 \\
2 \\
3\end{array}$ & $\begin{array}{l}\text { (2) } \\
\text { Antral }\end{array}$ & $\begin{array}{l}(3) \\
24 \\
0 / 10 \\
0\end{array}$ & $\begin{array}{l}(2) \\
22 \\
0 / 25 \\
0\end{array}$ & & $\begin{array}{l}(2) \\
26 \\
0 / 20 \\
0\end{array}$ & $\begin{array}{l}(1) \\
28 \\
0 / 21 \\
0\end{array}$ & & & & & 0 & 5 \\
\hline $\begin{array}{r}\text { G.M. } 1 \\
2 \\
3\end{array}$ & $\begin{array}{l}(2) \\
24 \\
0 / 38 \\
0\end{array}$ & $\begin{array}{l}(2) \\
12 \\
24 / 35 \\
++\end{array}$ & $\begin{array}{l}(1) \\
5 \\
6 / 25 \\
+\end{array}$ & $\begin{array}{l}(1) \\
5 \\
4 / 18 \\
+\end{array}$ & & & & & & & $\mathbf{0}$ & 3 \\
\hline $\begin{array}{r}\text { W.A. } 1 \\
2 \\
3\end{array}$ & $\begin{array}{l}\text { (2) } \\
\text { Antral }\end{array}$ & $\begin{array}{l}(3) \\
10 \\
0 / 8 \\
0\end{array}$ & $\begin{array}{l}(4) \\
32 \\
2 / 22 \\
+\end{array}$ & $\begin{array}{l}(2) \\
36 \\
0 / 12 \\
0\end{array}$ & $\begin{array}{l}\text { (2) } \\
\text { Antral }\end{array}$ & $\begin{array}{l}\text { (4) } \\
\text { Antral }\end{array}$ & $\begin{array}{l}\text { (2) } \\
\text { Antral }\end{array}$ & $\begin{array}{l}(2) \\
48 \\
2 / 26 \\
+\end{array}$ & & & 0 & 8 \\
\hline $\begin{array}{ll}\text { J.P. } & \mathbf{1} \\
& \mathbf{2} \\
\mathbf{3}\end{array}$ & $\begin{array}{l}\text { (4) } \\
\text { Antral }\end{array}$ & & $\begin{array}{l}(2) \\
22 \\
0 / 20 \\
0\end{array}$ & & $\begin{array}{l}(2) \\
18 \\
0 / 18 \\
0\end{array}$ & $\begin{array}{l}(4) \\
26 \\
0 / 50 \\
0\end{array}$ & & $\begin{array}{l}(4) \\
34 \\
0 / 23 \\
0\end{array}$ & $\begin{array}{l}(1) \\
11 \\
0 / 52 \\
0\end{array}$ & & 4 & 10 \\
\hline
\end{tabular}

Table II Serial gastric biopsies of seven patients before and during steroid administration

1 Number of sections examined (Number of biopsies in parentheses)

2 Glands containing parietal cells/total number of glands in section.

3 Number of parietal cells per gland scored from $\mathbf{0}$ to ++++ . 
result in this patient during steroid administration was $7 \%$. Achlorhydria returned after withdrawal of the drug.

\section{Circulating gastric antibodies}

Serum PCA was present in six out of seven patients and persisted throughout the period of steroid administration. In two patients only did the complement-fixation titre fall from $\frac{1}{64}$ to $\frac{1}{8}$ (patient $A D$, Table II) and from $\frac{1}{8}$ to $\frac{1}{2}$ (patient GM, Table II). Such falls did not correlate with recovery of gastric function.

In only one patient were serum intrinsic factor antibodies present initially and the titre did not change throughout the experiment.

\section{Gastric juice intrinsic factor antibodies}

Gastric juice was tested for intrinsic factor antibodies before steroid administration in four of the patients. Type I antibody was present in two and type II antibody was also present in one of these patients. Both antibodies persisted in this patient's gastric juice in spite of apparent improvement in $\mathbf{B}_{12}$ absorption (Schilling test, $1.0 \%$ before; $20 \%$ during treatment: patient AD, Table II). Type I intrinsic factor antibody disappeared from the gastric juice during prednisolone administration in the other patient who showed no clear response in the Schilling test (patient EC, Table II). Intrinsic factor antibodies appeared in the gastric juice of a further patient during prednisolone administration not having been detectable initially (patient GM, Table II).

\section{Gastric histology}

The seven patients were biopsied on 40 occasions and 101 specimens were obtained. Despite radiological positioning of the biopsy tube in the body of the stomach the mucosa was antral in type on 11 occasions and these specimens were therefore not utilized. No changes were observed in degree of mucosal atrophy or inflammation of the body of the stomach in any patient. Estimates of parietal cell counts are summarized in Table II. It should be stressed, however, that there was some variability in the number of parietal cells from one section to another in the serial biopsies and from one area of the stomach to another where multiple biopsies were taken. Parietal cells were present in biopsies taken from the body before commencement of corticosteroid administration in one patient and were not seen in biopsies taken before or shortly after commencement of the drug in the remainder. During administration of the drug some parietal cells were present in four of the seven patients in one or more biopsies. The numbers of these cells were small and no consistent trend was apparent during administration of prednisolone. No correlation between improvement of vitamin $B_{12}$ absorption and the presence of parietal cells was noted.

GROUP 3 : SHORT-TERM STEROID

ADMINISTRATION

Absorption of vitamin $B_{12}$

In three of the five patients vitamin $\mathrm{B}_{12}$ absorption was restored to the normal range $(11 \%, 11 \%$, and $10 \%$ respectively). Significant increases in absorption in these three patients appeared at eight, 11, and 13 days after commencing prednisolone (see Fig.). The maximal responses in vitamin $B_{12}$ absorption achieved by the remaining two patients were 6 and $3 \%$ respectively.

\section{Secretion of vitamin $B_{12}$ binders}

A definite increase in secretion of intrinsic factor was observed in only one patient (patient EK, see Fig.). Thus, despite frequent estimations during prednisolone administration, enhanced output could not be correlated with restoration of vitamin $B_{12}$ absorption to normal in these patients. The total $\mathrm{B}_{12}$ binding level in gastric juice, most of which was due to nonintrinsic factor $B_{12}$ binders, was extremely variable in all patients and no consistent trend was observed during prednisolone administration (Fig.).

\section{Acid secretion}

Thirty tests were performed in the five patients during corticosteroid administration and gastric anacidity ( $p \mathrm{H}$ above 6.5) persisted in all.

\section{Gastric antibodies}

Circulating parietal cell antibody was present in all five patients before prednisolone administration. A decrease in titre of this antibody estimated by complement fixation occurred in two patients (from $\frac{1}{16}$ to $\frac{1}{8}$ ) during prednisolone administration. One of these patients (DM, see Fig.) showed a functional response to prednisolone; the other did not.

\section{Serum and gastric juice intrinsic factor antibodies}

\section{Pretreatment}

Type I or II intrinsic factor antibody was detected in the serum of two of the three patients in whom vitamin $\mathbf{B}_{12}$ absorption was restored to normal during prednisolone administration (patients EK, EP, see Fig.). These antibodies were absent from the serum in the two patients in whom vitamin $\mathbf{B}_{\mathbf{1 2}}$ absorption was not significantly enhanced during corticosteroid administration and in one in whom restoration of absorption did occur (patient DM, 


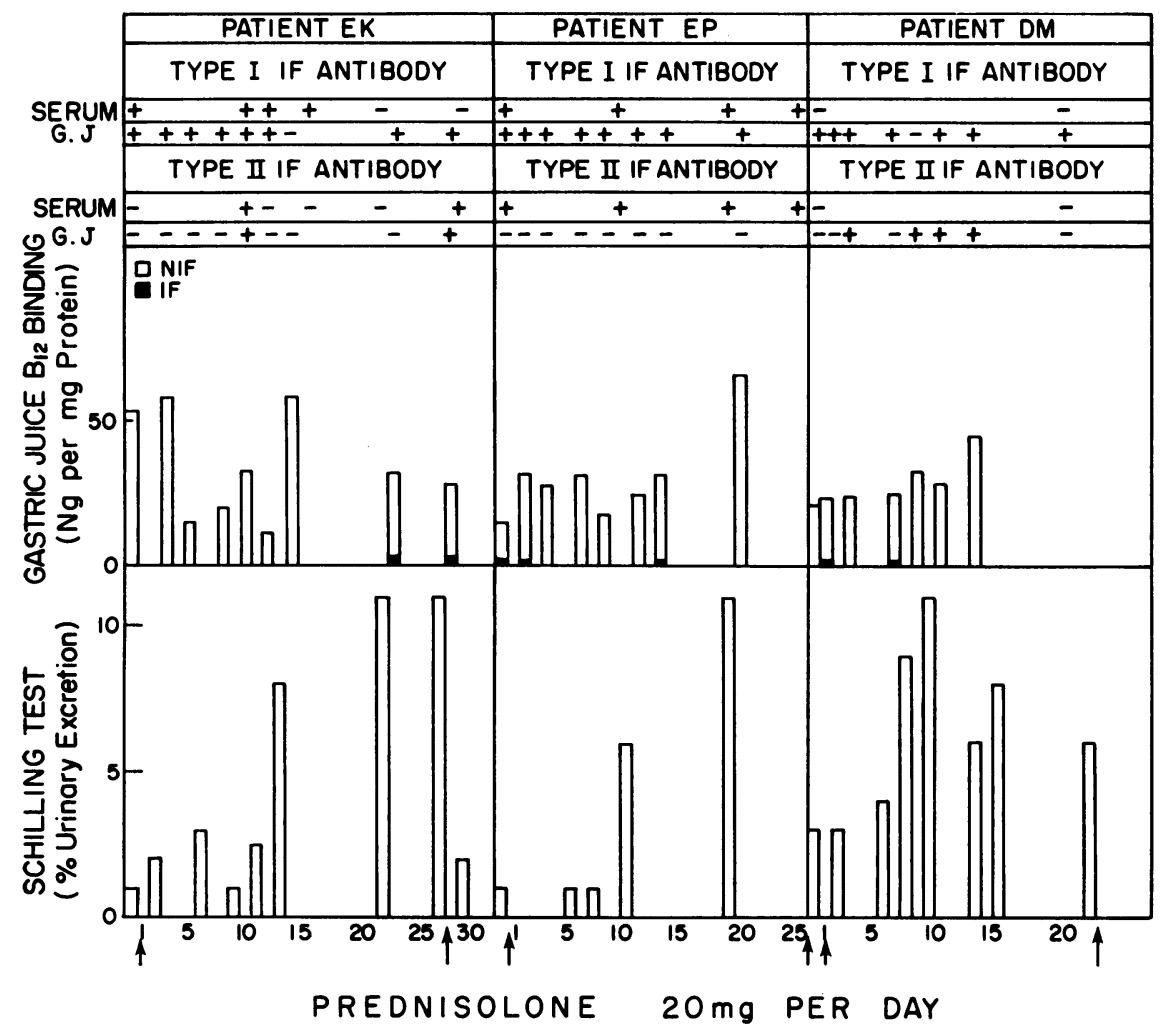

Fig. Effects of high doses of steroid for short periods in three subjects.

see Fig.). Type I or II intrinsic factor antibodies were detected in the gastric juice of all three patients in whom vitamin $\mathbf{B}_{12}$ absorption was restored and not in the unresponsive subjects.

\section{During prednisolone administration}

The titres of both type I and type II intrinsic factor antibodies in serum and gastric juice showed considerable variation. No consistent trend emerged. Although negative tests were obtained during prednisolone administration, these were not sustained and could not be correlated with either the restoration or continued normality of vitamin $B_{12}$ absorption. In two of the patients in whom the test for type II antibody in gastric juice had been negative initially, transiently positive results were observed during prednisolone administration (patients EK, DM, see Fig.)

\section{Gastric histology}

Gastric biopsies were obtained before and at the completion of the study period in the three patients who showed a functional response to prednisolone. The degree of atrophy and inflammation remained unaltered and no increase in specialized cells was observed in any of those patients.

\section{Discussion}

The reversal of vitamin $B_{12}$ malabsorption seen in seven of the 12 patients in the present study is in agreement with the observation that approximately $50 \%$ of patients with pernicious anaemia show such an effect during oral corticosteroid administration. (Østergaard Kristensen and Friis, 1960; Ardeman and Chanarin, 1965; Jeffries et al, 1966; Rødbro et al, 1967; Wall et al, 1968; Baggett and Welsh, 1970).

The mechanism of this effect has not been clearly established. In theory it might be mediated in a number of ways, operating singly or in unison. (1) Increased gastric secretion of intrinsic factor as a direct response of the mucosa to corticosteroids: increased stimulation of any parietal cells still present in a damaged mucosa might occur, or regeneration of new parietal cells be responsible, or both; (2) increased intrinsic factor-mediated absorption of vitamin $B_{12}$ in the small intestine; (3) increased non-intrinsic factor-mediated absorption 
of the vitamin; (4) an indirect effect, mediated through immunological changes, so that there was a reduction in inhibition of gastric intrinsic factor secretion by intrinsic factor antibodies, or of its activity by intrinsic factor antibodies in the gastrointestinal lumen or at the ileal receptor sites.

There is evidence that corticosteroids will increase acid secretion by the parietal cells of the healthy gastric mucosa (Strickland et al, 1969), which also are known to secrete intrinsic factor. In the present study there was no increase in absorption of vitamin $B_{12}$ or of gastric secretion of vitamin $B_{12}$ binders in healthy subjects without gastric mucosal disease or in subjects with a superficial gastritis unaccompanied by circulating gastric autoantibodies. These data suggest that corticosteroids exert an effect only when the gastric mucosa is markedly diseased and the production of intrinsic factor and absorption of vitamin $B_{12}$ severely impaired. They do not support the possibility of a direct effect on the small intestine. However, in the presence of an excess of intrinsic factor, a situation that obtains in health (Ardeman, Chanarin, and Doyle, 1964), any effect on nonintrinsic factor-mediated absorption might not be demonstrable.

The improvement of vitamin $\mathbf{B}_{12}$ absorption in patients with pernicious anaemia is generally attributed to an increase in intrinsic factor secretion during corticosteroid administration. The correlation is not, however, exact, and exceptions have occurred in four of the five previous studies (Ardeman and Chanarin, 1965; Jeffries et al, 1966; Wall et al, 1968; Baggett and Welsh, 1970) in which measurements of the intrinsic factor content of gastric juice by assay in vitro have been obtained before and during corticosteroid administration. An increase in intrinsic factor secretion was observed in our patients undergoing long-term administration of prednisolone. However, the present study of events occurring at the gastric level early in the course of prednisolone administration clearly indicates that reversal of vitamin $B_{12}$ malabsorption can occur independently of enhanced intrinsic factor secretion.

The possibility that intrinsic factor antibodies in pernicious anaemia might interfere either with production of intrinsic factor or its activity led us to examine whether corticosteroids exert any suppressive effect on these autoantibodies in serum or gastric juice and so account for the enhancement of vitamin $B_{12}$ absorption. Reduction in the titre of circulating intrinsic factor antibody during corticosteroid administration has been observed but there has been no correlation with the observed functional improvement (Ardeman and Chanarin, 1965; Jeffries et al, 1966; Rødbro et al, 1967; Wall et al, 1968; Taylor, 1959; Baggett and Welsh, 1970).
The findings of the present study are in agreement with these previous observations. The frequent observations on circulating intrinsic factor antibodies during short-term prednisolone administration revealed variations in titres with no consistent trend and no relationship in time to the functional changes. It is possible that the observations represent natural variation of antibody titre, entirely independent of prednisolone. If suppression of intrinsic factor antibody was important in the restoration of vitamin $\mathbf{B}_{12}$ absorption to normal during corticosteroid administration, events at the gastric level would be more likely to reveal significant alterations than those in the serum. In the present study the effect of prednisolone on intrinsic factor antibodies in gastric juice has been investigated and a pattern similar to that seen in the serum was observed. Variation in titre, independent of the functional changes and with no consistent trend, was again noted. These findings both in serum and gastric juice indicate that the restoration of vitamin $B_{12}$ absorption to normal cannot be attributed to suppression of intrinsic factor antibody at either site, a recent conclusion also of Baggett and Welsh (1970).

The histological changes in the gastric mucosa observed in our patients with pernicious anaemia during corticosteroid administration are at variance with previous studies. We have not been able to document a consistent reappearance of parietal cells in individual patients and a correlation between the presence of parietal cells and a functional response was not evident.

There is a general agreement that neither the basic appearances of atrophy with intestinal metaplasia, nor the degree of inflammatory cellular infiltration, change during corticosteroid administration. However a return of small numbers of parietal cells has been reported to occur and occasionally patients will secrete small quantities of acid (Ardeman and Chanarin, 1965; Jeffries et al, 1966; Rødbro et al, 1967; Wall et al, 1968; Baggett and Welsh, 1970). Acid secretion was not observed in any of our patients studied intensively over a month but did appear in one patient after five months of prednisolone. The correlation between apparent return of parietal cells to the gastric mucosa and corresponding functional improvement has been inexact. The study of Rødbro et al (1967) showed a striking lack of correlation. In six patients who showed a functional response to prednisolone, four showed apparent parietal cell regeneration. However, a similar histological response was recorded in four of 11 patients who showed no functional improvement. The gastric atrophy of pernicious anaemia is not invariably complete and small foci of surviving specialized glandular cells have been noted in up to 
one third of patients (Williams, Coghill, and Edwards, 1958). Accordingly parietal cells may be seen in biopsies taken before corticosteroid administration in some patients. In the study of Baggett and Welsh (1970) parietal cells were present in gastric biopsies from nine of 11 patients before prednisolone. In only two of nine patients biopsied during corticosteroid administration could they show that the parietal cell population had increased and in neither of these patients was a functional response demonstrated.

It is evident, therefore, that the assessment of minor histological changes during corticosteroid administration in the small specimens obtained by tube biopsy may be very difficult to interpret. An additional problem evident from our own study is that, despite positioning the biopsy tube under fluoroscopy in the body of the stomach, specimens of gastric mucosa obtained from this site in pernicious anaemia are antral in type, due perhaps to metaplastic change. We contend that such specimens should not be used to study the influence of corticosteroids on the parietal cell-bearing area of the gastric mucosa.

We conclude from the present study that the undoubted reversal of vitamin $B_{12}$ malabsorption in some patients with pernicious anaemia taking oral corticosteroids cannot be wholly explained by a direct effect on gastric parietal cells. An additional effect at the small intestinal level is suggested by the poor correlation with events observed in the stomach. The possibility must be entertained that corticosteroids may influence non-intrinsic factormediated absorption of $\mathrm{B}_{12}$ in the small intestine.

This work was supported in part by grants AM-0828 and AM-06971, and training grant AM-05418 from the National Institutes of Health, United States Public Health Service; grant RR-70 from the General Clinical Research Center's program of the Division of Research Resources, National Institutes of Health; the Veterans Administration Hospital, Palo Alto; and a grant from Merck, Sharp and Dohme, Inc. Dr Fisher was a recipient of a research fellowship award, California Division, American Cancer Society (Dernham Fellowship J-111).

The authors are grateful to Miss Mozetta Taylor Mrs Betty Loyd, and Miss Nancy Koo for their technical assistance, and Dr E. Alpert and Merck, Sharp and Dohme, Inc., for supplying the prednisolone. They also wish to thank Mr R. Urbino and his staff at the California Medical Faculty at Vacaville for their valuable assistance throughout the study.

\section{References}

Ardeman, S., and Chanarin, I. (1965). Steroids and Addisonian pernicious anemia. New Engl. J. Med., 273, 1352-1355.

Ardeman, S., Chanarin, I., and Doyle, J. C. (1964). Studies on secretion of gastric intrinsic factor in man. Brit. med. J., 2, 600-603.

Ashworth, L. A. E., England, J. M., Fisher, J. M., and Taylor, K. B. (1967). A new method for detection and measurement of intrinsic factor antibodies. Lancet, 2, 1160-1164.

Baggett, R. T., and Welsh,'J. D. (1970). Observations on the effects of glucocorticoid administration in pernicious anemia. Amer. J. dig. Dis., 15, 871-881.

Brandborg, L. L., Rubin, C. E., and Quinton, W. E. (1959). A multipurpose instrument for suction biopsy of the esophagus, stomach, small bowel and colon. Gastroenterology, 37, 1-16.

Donnelley, M. (1951). Studies in experimental immunology of influenza. VII. An improved complement-fixation technique. Aust.J. exp. Biol. med. Sci., 29, 137-146.

Fisher, J. M., Mackay, I. R., Taylor, K. B., and Ungar, B. (1967). An immunological study of categories of gastritis. Lancet, 1, 176180.

Gottlieb, C., Lau, K. S., Wasserman, L. R., and Herbert, V. (1965). Rapid charcoal assay for intrinsic factor (IF), gastric juice unsaturated $B_{12}$ binding capacity antibody to IF, and serum unsaturated $\mathrm{B}_{12}$ binding capacity. Blood, 25, 875-884.

Jeffries, G. H., Todd, J. E., and Sleisenger, M. H. (1966). The effect of prednisolone on gastric mucosal histology, gastric secretion, and vitamin $B_{12}$ absorption in patients with pernicious anemia. J. clin. Invest., 45, 803-812.

Lowry, O. H., Rosebrough, N. J., Farr, A. L., and Randall, R. J. (1951). Protein measurement with the Folin phenol reagent. $J$. biol. Chem., 193, 265-275.

Østergaard Kristensen, H. P., and Friis, T. (1960). Effect of prednisone on $\mathrm{B}_{12}$ absorption in pernicious anaemia. Acta med. scand., 166, 249-254.

Rødbro, P., Dige-Petersen, H., Schwartz, M., and Dalgaard, O. Z. (1967), Effect of steroids on gastric mucosal structure and function in pernicious anemia. Acta med. scand., 181, 445-452.

Strickland, R. G., Ashworth, L. A. E., Koo, N. C., and Taylor, K. B. (1969). Intrinsic factor, nonintrinsic factor vitamin $B_{12}$ binder and pepsinogen secretion in normal subjects: quantification using intragastric neutralization and inorganic phosphate as marker. Gastroenterology, 57, 511-517.

Strickland, R. G., Baur, S., Ashworth, L. A. E., and Taylor, K. B. (1971). A correlative study of immunological phenomena in pernicious anaemia. Clin. exp. Immunol., 8, 25-36.

Strickland, R. G., Fisher, J. M., and Taylor, K. B. (1969). The effect of prednisolone on gastric function and structure in man. Gastroenterology, 56, 675-686.

Taylor, K. B. (1959). Inhibition of intrinsic factor by pernicious anaemia sera. Lancet, 2, 106-108.

Wall, A. J., Whittingham, S., Mackay, I. R., and Ungar, B. (1968). Prednisolone and gastric atrophy. Clin. exp. Immunol., 3, 359-366.

Williams, A. W., Coghill, N. F., and Edwards, F. (1958). The gastric mucosa in pernicious anaemia : biopsy studies. Brit. J. Haemat., 4, 457-464. 